\title{
Editorial
}

\section{INASP support to improve medical journals of developing countries: BJMS experience}

\author{
Abu Kholdun Al-Mahmood
}

A scientific journal is a periodical publication intended to further the progress of science, usually by reporting new research. There are many journals all over the world which are often highly focused. It is a prestige to get through a report of new research in a reputed journal. However, publishing in the leading journals, though tempting, is always a big ask. Not only does it require breakthrough finding but also language skill. Preparation of manuscript to some extent is a matter of practice.

People are engaged in research in the field of medicine. But number of publications of new research in international journals is small. These are actually reports of collaborative research with international contacts. In most of the cases reports are published in the national non-indexed journals which remain unheard by the researchers of other countries. A vacuum has been felt for internationally reputed peer reviewed journal in the country which can act as light house in the field of scientific publications.

Ibn Sina Trust, a philanthropic charitable non-government healthcare based organization, came forward and publishing a peer reviewed journal 'Bangladesh Journal of Medical Science (BJMS)' to provide chance to Bangladeshi researchers to disseminate their results and experience. The publisher has a promise to raise and maintain the standard of the journal. Its print only version remained unnoticed to the international community. Efforts were initiated to reach out international scientist community which was later materialized when it got support from International Network for the Availability of Scientific Publications (INASP) and published online. Subsequently there has been another breakthrough that Ibn Sina Medical College became a member of Consortium of Islamic Medical Colleges (CIMCO).

First printed issue of BJMS was published in the middle of the year 2009. It contained 6 articles, of them only one was foreign ${ }^{1}$ which was collected by personal communication of the editor. For the next issues there has been long wait for submission from authors, a common experience for most journal editors of Bangladesh. Once the journal published electronically there was a dramatic change in flow of submission of manuscript. We had the experience of getting articles from Malaysia, India and Pakistan. The third issue of 2009 contained 7 articles of which 4 were from abroad $\stackrel{2-5}{{ }^{2}}$

CIMCO membership of Ibn Sina Medical College also opened another horizon. We are linked to medical scholars of different countries through CIMCO and getting solicited/invited editorials. The editorials contained directions on sophistication of medical writings $^{2}$, morality in medical education ${ }^{6-7}$, revival of research in developing Muslim world ${ }^{8}$, ethical issues in genetic and reproductive technologies ${ }^{9}$, on cardiovascular epidemic and many diverse issues which add a lot in our knowledge arena. Out of 12 published editorials 10 were from foreign authors.

We published 63 original articles, 11 review articles and 40 case reports. Articles include basic studies on molecular factors behind diabetes ${ }^{10-11}$, use of therapeutic laser $^{12}$, forensic identification ${ }^{13}$, medicinal plants $^{14-15}$, and many other issues. Thousands of downloads proven the usefulness of these publications. Few rare case reports were published in last few years i.e. full term ectopic pregnancy ${ }^{16}$, corneal abrasion during ENT surgery ${ }^{17}$, thoracopagus conjoined twin $^{18}$, Edward's syndrome ${ }^{19}$, Lingual thyroid $^{20}$, spontaneous extrusion of migrated fish bone in the neck ${ }^{21}$, fish bone piercing epiglottis ${ }^{22}$. All these publications were read by wide range of readers round the world.

Out of 126 published articles so far 76 were from abroad which include countries like India, Malaysia, Pakistan, Turkey, Japan, Australia, Nigeria, Iran, China, Ethiopia, Thailand, Sudan, Saudi Arabia and Belgium. INASP collaboration played a pivotal role in giving the journal an international-intercontinen- 


\section{Abu Kholdun Al-Mahmood}

tal identity. CIMCO faculties helped a lot in getting and reviewing articles without any fees.

INASP and CIMCO support also helped increasing number of readers. Until March 2012 more than 53,902 readers from more than 100 countries downloaded articles from our journal. The journal impact analysis through 'Harzing's Publish or Perish' showed 27 citations with an 'h-index: 2', 'hc-index: 3 ' which reflects increasing usefulness of the journal.
Meanwhile it has been indexed by Index Copernicus, DOAJ, HINARI, CrossRef, EBSCO Library and British Library.

Finally we can conclude that the advocacy of INASP have immense effect in raising quality, availability, usefulness of BJMS. We hope to strengthen cooperation further.

\section{References:}

1. Musa MN. Rumah Solehah-Malaysia: Half way home for the Women and children with HIV/AIDS. Bangladesh Journal of Medical Science 2009; 8(1): 28-31.

2. Iqbal Khan M. Sophistication of Medical Writings. Bangladesh Journal of Medical Science 2009; 8(3): 44-45.

3. Hussain F, M Arif Maan, MA Sheikh, H Nawaz, A Jamil. Trace elements status in type 2 diabetes. Bangladesh Journal of Medical Science 2009; 8(3): 52-56. http://dx.doi.org/ 10.3329/bjms.v8i3.3983

4. Shaju Jacob P, Zade RM. Width of attached gingival in an Indian population: A descriptive study. Bangladesh Journal of Medical Science 2009; 8(3): 64-67.

5. M Irfan, SA Halim, AM Khir. Infratemporal neurofibroma presenting as a parotid mass. Bangladesh Journal of Medical Science 2009; 8(3):

72-74. http://dx.doi.org/10.3329/bjms.v8i3.3987

6. Abdul Latif Mohamed. Future challenges in medical education. Bangladesh Journal of Medical Science 2010; 9 (1): 04-13.

7. Iqbal Khan M. Towards the preparation of highest quality medical professionals. Bangladesh Journal of Medical Science 2010; 9(3): 116-129.

8. ARA Rashid. Increasing Muslim contribution to
Medical research: reviving a lost legacy. Bangladesh Journal of Medical Science 2010; 9(2): 56-59.

9. Musa MN. Human genetic and reproductive technologies an international medico-legal-religious impasse?. Bangladesh Journal of Medical Science 2009; 10(1): 001-010.

10. Hussain F, M Arif Maan, MA Sheikh, H Nawaz, A Jamil. Trace elements status in type 2 diabetes. Bangladesh Journal of Medical Science 2009; $\quad \mathbf{8 ( 3 ) :}$ 52-56. http://dx.doi.org/10.3329/bjms.v8i3.3983

11. Hussain F, M Arif Maan, M Farida. Plasma protein glycation status in Pakistani type 2 diabetic patients. Bangladesh Journal of Medical Science 2010; 9(2): 60-67.

12. Suhaimi MJ, Zahra JAT. Therapeutic laser for chronic low back pain. Bangladesh Journal of Medical Science 2009; 8(4): 118-128.

13. Kinoshita H, Tanaka N, Ohi T, Jamal M. Prior surgical intervention of the bone; useful finding for the examination of the skeletal remains. Bangladesh Journal of Medical Science 2010; 9(2): 93-94.

14. Nanjunda DC. Ethno-medico-botanical investigation of Jenu Kuruba ethnic group of Karnataka state, India. Bangladesh Journal of Medical Science 2010; 9(4): 161-169.

15. S Sakila, N Begum, S Kawsar, ZA Begum, MS 
INASP support to improve medical journals of developing countries: BJMS experience

Zoha. Relationship of anti fertility effects of Andrographis paniculata and hormonal assay in female rats. Bangladesh Journal of Medical Science $\quad 2009 ; \quad \mathbf{8}(1)$ : 10-14. http://dx.doi.org/10.3329/bjms.v8i1.3183

16. Abeda K, Laila A. Term alive intra abdominal ectopic pregnancy. Bangladesh Journal of Medical Science 2012; 11(1): 68-70. http://dx.doi.org/10.3329/bjms.v11i1.9828

17. Irfan M, Wong CY, Siti RI. A rare complication of corneal abrasion in otorhinolaryngology procedure: Lessons learnt. Bangladesh Journal of Medical Science 2011; 11(1): 63-64.

18. Sharmin F, Begum F, Parveen T, Khatun SF, W Fatima. Thoracopagus conjoined twin - a case report. Bangladesh Journal of Medical Science 2011; 10(4): 289-294.
19. Patra S, Singal KK, Singh B. Edward's syndrome with novel karyotype. Bangladesh Journal of Medical Science 2011; 10(3): 211212.http://dx.doi.org/10.3329/bjms.v10i3.8368

20. AR Roselinda, H Salina, KN Gopalan, Primasha Putra. Functional lingual thyroid in an adolescent female: a case report. Bangladesh Journal of Medical Science 2011; 10(3): 216-218.

21. S Jamal, M Irfan, N Nazim. Spontaneous extrusion of migrated fish bone in the neck after 48 hours of ingestion: a case report. Bangladesh Journal of Medical Science 2011; 10(1): 129132.

22. Nik Fariza NH, Irfan M, Ramiza RR. Fish bone piercing epiglottis: a case report. Bangladesh Journal of Medical Science 2010; 9(1): 53-55. 